\title{
La otra cara de la fiesta: algunas de sus posibles repercusiones económicas
}

\author{
Josefina Castilla Soto*
}

\begin{abstract}
RESUMEN
ABSTRACT

Con el presente artículo hemos In this article we have wished to state a different point of view with regard to the theme devoted to a single subject that concerns us: some of the feast days' negative repercussions throughout the agricultural, comercial scopes, for the creation of brotherhoods, etc..., in the light of contemporaries' pouring criticism, specially promoters of crackpot and thinkers of $17^{\text {th }}$ and $18^{\text {th }}$ century.
\end{abstract}

\section{INTRODUCCIÓN}

Las fiestas, como fenómeno eminentemente social, se traducían en la España Moderna en múltiples manifestaciones de indole religiosa y profana. Concretamente se pueden distinguir las fiestas emanadas del poder político, en su vertiente pública y privada, las del poder religioso, en su vertiente ritual y de ostentación y las fiestas genuinamente populares aunque causadas casi siempre por la vía religiosa ${ }^{1}$. Son innu-

\footnotetext{
* Departamento de Historia Medieval y Moderna. UNED.

DíEz BOROUE, J. Ma., Teatro y fiesta en el barroco. España e lberoamérica. Barcelona, 1986, pág. 11.
} 
merables los trabajos dedicados a los múltiples aspectos de las demostraciones festivas y desde los más variados puntos de vista. Historiadores, antropólogos, sociólogos... han utilizado ríos de tinta para narrarlos, recrearlos o interpretarlos. Resultaría totalmente imposible mencionar tantas obras dedicadas a las fiestas en la España Moderna, sirva por ello el botón de muestra representado por este número de nuestra revista, Espacio. Tiempo y Forma. Sin embargo, con este artículo hemos intentado poner de manifiesto un punto de vista diferente respecto al tema monográfico que nos ocupa: la excesiva proliferación de fiestas religiosas y sus posibles repercusiones negativas en el ámbito económico. A tal fin hemos utilizado, como fuentes fundamentales, las críticas vertidas por los contemporáneos, a lo largo de los siglos modernos.

\section{PANORAMA FESTIVO NACIONAL Y LOCAL}

Sería interesante, pues, dibujar el panorama festivo-religioso que aparecia en la España Moderna. La península, como parte integrante de la cristiandad medieval, se hallaba lógicamente bajo la disciplina de la Iglesia Católica, la cual, aparte de normas estrictamente litúrgicas, había promulgado también unas determinadas leyes jurídicas en su ordenamiento, que representaban el derecho común de la Iglesia de entonces.

Así, el Decreto de Graciano (1130-1140) ofrece la siguiente lista de fiestas de guardar para todos los cristianos ${ }^{2}$ : todos los domingos del año, el día de Navidad, San Esteban, San Juan Evangelista, Inocentes, San Silvestre, Octava de Navidad, Epifania, Purificación de Santa María, Pascua con toda la semana siguiente, los tres días de Rogaciones, la Ascensión, Pentecostés, San Juan Bautista, los doce Apóstoles (en especial San Pedro y San Pablo), San Lorenzo, Asunción de Santa María, Natividad de Santa María, dedicación de cada Iglesia, San Miguel Arcángel, dedicación de cada oratorio, Todos los Santos, San Martín.

En 1298 el Liber Sextus de Bonifacio VIII reproducía una decretal de este Papa, en la que se ordenaba celebrar con oficio de rito doble, las fiestas de los doce Apóstoles, de los cuatro Evangelistas y de los cuatro Doctores de la Iglesia latina: San Agustín, San Ambrosio, San Jerónimo y San Gregorio.

GarcIa $\vee$ Garcia, A., "Religiosidad popular y festividades en el occidente peninsular (s. XIIIxvI)», Actas del Coloquio Fiestas y Liturgia. Madrid, 1988, pág. 36. 
Éste sería, a grandes rasgos, el cuadro que el derecho común de la cristiandad medieval ofrecia en relación con las festividades religiosas, cuadro que heredaría posteriormente la España Moderna.

Pero además, el mismo capítulo gracianeo mencionado anteriormente, concluía admitiendo que los obispos podian instituir otras festividades a escala local. De hecho, frente a la sobria lista de fiestas de precepto, representativa del derecho común de la cristiandad medieval, los sínodos ofrecen prolijas listas de santos cuyas festividades eran preceptivas para la respectiva diócesis ${ }^{3}$. Estas fiestas se introducían, en ocasiones, por iniciativa del pueblo, y otras por la del propio obispo. Sin embargo, la religiosidad popular no estaba ligada a jerarquías sociales, era más bien una manera de sentir, de vivir la religión. Por ello, su dominio no era la doctrina, el dogma, sino la ceremonia, el rito,... ${ }^{4}$. Generalmente, Iglesia y pueblo comulgaban en la misma fe en lo maravilloso, en el mismo afán por contemplar prodigios e intervenciones de la divinidad en todas partes.

Lo cierto es que en las aldeas, pueblos y ciudades de España convivían dos tipos de catolicismo: el de la Iglesia Universal, basado en los sacramentos, la liturgia y el calendario romano, y otro local, basado en lugares, imágenes y reliquias de carácter propio, en santos patronos de la localidad, en ceremonias peculiares y en todo un singular calendario compuesto a partir de la propia historia sagrada del pueblo ${ }^{5}$.

Resulta indudable que una población grande podía organizar celebraciones, procesiones y festejos a escala más impresionante que una pequeña aldea. De hecho, la riqueza de las ciudades y lo mucho que dependia de ella la hacienda real, les proporcionaba mayores posibilidades a la hora de obtener indulgencias y jubileos para sus particulares festividades, hacerse con reliquias o ver canonizados a sus santos.

Pero si en el Renacimiento se intentó caminar hacia una religiosidad interior, más alejada de las ceremonias, en virtud de un espíritu más crí-

Ibidem, pág. 40.

DOMinguez ORtiz, A., "Iglesia institucional y religiosidad popular en la España barroca", Actas del Coloquio La Fiesta, la ceremonia, el rito. Granada, 1990, pág. 10.

Christian, W.A., Jr., Religiosidad local en la España de Felipe II. Madrid, Nerea, 1991, pág 17. Se trata de un estudio de las creencias y la práctica religiosa, basado en las respuestas recogidas en las "Relaciones Topográficas" de Felipe II. Sobre este tema de religiosidad localista véase también Campos y Fernandez de Sevilla, F.J., La mentalidad de Castilla la Nueva en el siglo XV! (reiigión. economia y sociedad, según las "Relaciones Topográficas" de Felipe II). El Escorial, 1986. 
tico que luchaba contra la milagreria, las falsas reliquias, etc..., la reacción tridentina cortó esa evolución y volvió a aproximar ambas corrientes mediante una doble operación: por un lado se introdujeron bastantes reformas, encaminadas a depurar las costumbres religiosas locales que rozaran la superstición, garantizar que estuvieran bajo el control de su respectiva diócesis y eliminar todo cuanto pudiera hallarse en conflicto con la normativa emanada de Roma ${ }^{6}$. Porque la Iglesia desconfiaba de las manifestaciones piadosas que llevaban a relacionar al pueblo directamente con la Divinidad, mientras que sancionaba aquellas otras en las que intervenía el sacerdote con sus oraciones, o simplemente con su presencia.

Pero Trento, por otro lado, contribuyó a favorecer las ceremonias de raíz populista: romerías, procesiones, culto a las imágenes, a las reliquias,... ?

Ello explica la multiplicidad de ocasiones que se presentaban en las ciudades de la España Moderna para la celebración de una fiesta. Aparte las propias del calendario litúrgico, las más frecuentes se daban con motivo de ${ }^{8}$ : dedicación de iglesias, consagración de nuevos santuarios, fundación o traslado de conventos, presentación y traslado de reliquias, traslado de imágenes, fiestas de órdenes religiosas, fiestas de gremios, rogativas, beatificaciones y canonizaciones, dogmas.

Esto llevó a Fernández Navarrete a afirmar que en muchos obispados, las fiestas de guardar pasaban de la tercera parte del año ${ }^{9}$.

Dado que nuestro objetivo es presentar una panorámica de las festividades religiosas existentes en la España Moderna, con el fin de calibrar las críticas dirigidas hacia su excesiva proliferación y sus nefastas consecuencias en la economía de la época, conviene recordar que toda festividad religiosa, aparte de las ceremonias y ritos propios de la liturgia, llevaba aparejadas multitud de manifestaciones traducidas en juegos (de cañas, cucañas, pelota), luminarias y fuegos de artificio, toros ("corridas", vaquillas, toros embolados, toros de fuego), etc...

\footnotetext{
Christian, W. A., Jr., op. cit., pág. 198.

Dominguez Ortiz, A., "Iglesia institucional...", op. cit., pág. 10.

Diez Boroue, J.Ma., op. cit., págs. 16-17.
}

9 Fernandez Navaraete, P., "Conservación de monarquías y Discursos políticos sobre la gran consulta que el Consejo hizo al Señor Rey Don Felipe III", en Obras de Don Diego de Saavedra Fajardo y del licenciado Pedro Fernández Navarrete, Biblioteca de Autores españoles (BAE), t. XXV, Discurso XIII. Esta obra se encuentra también en Biblioteca Nacional de Madrid (BNM), R. 11316 y R. 16633. Además una copia del Discurso XIII, sin nombre ni fecha, se localiza en BNM, Mss. 10930, fols. 119-126. 


\section{REPERCUSIONES ECONÓMICAS}

En medio de este panorama en exceso festivo, pronto surgieron voces dispuestas a achacar la decadencia española, entre otras causas, a la proliferación de actos y fiestas de guardar ${ }^{10}$.

En particular, en los comienzos del siglo XVII tomó estado oficial la cuestión de los «males de España». Fue entonces cuando surgió una nube de escritores políticos y de economistas pragmáticos que destinaron sus observaciones y conocimientos a manifestar los «males» y sus posibles soluciones, independientemente de que el fenómeno arbitrista se haya dado también en otras muchas épocas y lugares. Sin embargo, baste señalar que Hamilton, por ejemplo, destacó que durante la gran decadencia española, los economistas, por una vez, dieron con el diagnóstico y con los remedios ${ }^{11}$.

A comienzos del siglo XVII Fernández Navarrete expresaba así las repercusiones que las fiestas tenían en los trabajadores españoles:

"Y si se pondera con atención, se hallará que cada día de fiesta, cesa en España una infinita suma de intereses, que ganaran los jornaleros y oficiales mecánicos; que porque causará admiración, no digo el tanteo, que por mayor tengo hecho, siendo fácil el juzgar, que forzosamente será más grande en tanto número de laborantes que dejan de trabajar ${ }^{12}$.

\section{Una centuria después el Padre Feijóo sí se atrevió a ofrecer ese «tanteo»:}

"Danse comúnmente de población a España, ocho millones de almas, o poco más. Más de la mitad de éstas se ejercitan en la agricultura y otras artes mecánicas. Pongamos que el trabajo de cada individuo, computado uno con otro, no valga más que real y medio de vellón cada día. Sale a la cuenta que en cada dia festivo, por cesar el ejercicio de todas aquellas artes,

\footnotetext{
10 Fernanoez Navarrete, P., “Papel sobre la muchedumbre de fiestas de guardar que hay en España», en BNM, Mss. 10930, fols. 119-126. Precisamente Dominguez Ortiz señala, que a pesar de los deseos de la Iglesia de proclamar austeridad y de las calamidades por las que atravesaba el pueblo en el siglo XVII, también las fiestas religiosas constituían una explosión de bullicio, ruido y música. Quizá por esa misma decadencia se produjo una reacción que multiplicó las ocasiones de fiesta. Dominguez Ortiz, A., "Iglesia institucional...", op. cit., pág. 15. Y de ahí sin duda, los intentos de arbitristas, pensadores y religiosos por reducir su número.

11 HAMILTON, E.J., "Spanish mercantilism before 1700 " y "The decline of Spain", en El florecimiento del capitalismo. Madrid, 1948, págs. 131 y 203. No vamos a profundizar aquí en lo que supuso para España la crisis del siglo xvII sobre la que tanto se ha escrito. Simplemente nos limitaremos a establecer aquellos aspectos relacionados con el tema concreto que nos ocupa.

iz Fernández Navarrete, P., op. cit., Discurso XIII.
} 
pierde España seis millones de reales. Por consiguiente, si en todo el año se cercenasen no más que quince días festivos, se interesaría el reino en seis millones de pesos" ${ }^{13}$.

Curiosamente el establecimiento de las fiestas, sobre todo locales, se correspondía, a lo largo del año, con los quehaceres estacionales de forma que los rituales se encontraban jalonando el transcurrir de las actividades económicas ${ }^{14}$. Así, las fiestas más celebradas tenían lugar en agosto, lo que significaba un alto en las tareas del campo y sus consiguientes pérdidas para los trabajadores:

"...se hallará que el mes de agosto, que es el más ocupado de todo el año con la cosecha de los labradores, tiene tantas fiestas como días feriados" 15 .

De esta manera, el jornalero no sólo dejaba de percibir su salario sino que sus gastos se incrementaban por doble motivo: los costes que suponian el mantenimiento de sus ayudantes o mozos, animales de labor...así como los generados por la celebración festiva en sí misma.

"Y asimismo se debe ponderar, que no sólo recibe el daño el labrador con cesar su trabajo personal, sino que los criados y mozos de campo, las mulas y los bueyes, le hacen costa y gasto todo el año, sin servirle más que dos tercias partes de él” ${ }^{16}$.

Las celebraciones festivas suponian, por regla general, gastos extraordinarios derivados de cierta ostentación que solía hacerse en ellas, tanto a nivel gastronómico como en el vestir:

"...juntamente de consumir, como lo hacen en un día de fiesta, lo que ganaron en seis de labor (...); si por otra parte se gastan y consumen las haciendas en juegos y glotonerías y vicios" ${ }^{17}$.

\footnotetext{
:3 FEIJOO, Fray B. J., "Teatro Crítico Universal», t. VI (paradojas políticas y morales: parado. ja segunda) en Obras escogidas del Padre Feijóo, BAE, t. LVI, pág. 276. Feijóo, consciente del retraso intelectual de España, publicó toda la riqueza de sus conocimientos en una serie de ensayos que en definitiva constituyen su Teatro Crítico Universal. Al comienzo del siglo xvm se había llegado con una sensación de derrota y de desgaste material que había transmitido la centuria anterior. Dicha herencia se agravó más con motivo de la Guerra de Sucesión. Obviamente, se imponía una actitud critica encabezada por el Padre Feijóo el cual diagnosticaba y recetaba al mismo tiempo.

VELASCO, H. M., "Mayo en julio. Rituales festivos entre el ciclo anual y el ciclo de la vida", Actas del Coloquio Fiestas y Liturgia. Madrid, 1988, pág. 135.

Fernandez Navarrete, P., op. cit., Discurso XIII.

Ibidem, Discurso XIII.

Ibidem, Discurso XIII.
} 
Lo cierto era que la penuria económica afectaba en mayor medida al jornalero, que dependía de su jornal, el cual correspondía a lo que en cada pueblo se consideraba cantidad necesaria para el mantenimiento diario de ellos y de sus familias. Campomanes resumía:

«El jornalero gana cuanto más, cuatro reales o cuatro reales y medio. Descontando los dias de fiesta, los que está enfermo o en que le falta trabajo, vive una gran parte del año sin auxilio" ${ }^{18}$.

Sin embargo, también el comercio se vio afectado por la proliferación de festividades religiosas. De hecho, en las constituciones sinodales aparecían repetidas prohibiciones de celebrar ferias y mercados porque impedían la asistencia a misa y la santificación de determinados días ${ }^{19}$. Ello unido al aumento de los precios y de los salarios ${ }^{20}$ facilitó la entrada en España de las mercaderias extranjeras.

Indudablemente, el tema de la entrada en España del comercio extranjero dio paso a muy diferentes enfoques entre los "primitivos" españoles del pensamiento económico. Todavía en el siglo xvi, Luis Ortiz en su Memorial denunciaba la salida de España de materias primas (lana, seda, hierro) y la importación de manufacturas, lo que provocaba la subida de precios:

"Ésta es la causa no sólo de llevarnos el dinero, más de que en estos reinos valgan las cosas tan caras por vivir por manos ajenas, que es vergüenza y grandísima lástima de ver y muy peor lo que burlan los extranjeros de nuestra nación, que cierto en esto y en otras cosas nos tratan peor que a indios..." ${ }^{21}$.

Sin embargo, a comienzos del siglo XVII, Fernández Navarrete culpaba a las fiestas del aumento de precios y como consecuencia de ello, de la entrada de mercancias extranjeras:

"También se origina de muchedumbre de fiestas, el haber subido todo lo vendible a precios excesivos, pues por cesar tantos días los labradores, es

\footnotetext{
: Recogido por Donezar diez de Uizugrun, J. Ma., Riqueza y propiedad en la Castilla del Antiguo Régimen. Madrid, 1996, pág. 456.

Garcia Garcia, A, op. cit., pág. 42

Algunos, como Fehnandez Navaraete, achacaban la subida de precios, entre otras causas, a la elevación de los jornales de los labradores, los cuales compensaban asi los días festivos no trabajados. Otros, como Fray Juan Martínez, confesor de Felipe IV, preferian justificar la subida de los jornales por la elevada despoblación que sufría España. Estas opiniones del confesor en Dominguez Ortz, A., Estudios de Historia Económica y Social de España. Granada, 1988, pág. 217.

Recogido por VILAR, P., Crecimiento y desarrollo. Barcelona, Ariel, 1980, pág. 152
} 
forzoso crezcan los jornales de los laborantes, con que se ha abierto puerta a que de provincias y reinos extraños, donde por haber más oficiales mecánicos y menos fiestas, son más bajos los precios de las labores, se traigan a España infinitas mercaderías necesarias y no necesarias; sacando con lo industrial de la manufactura, la riqueza de oro y plata, que son los principales frutos que tiene esta Monarquía" ${ }^{22}$.

Por la misma época, Sancho de Moncada insistía, fundamentalmente, sobre el daño que el comercio extranjero causaba en España:

"La razón primera es, porque con este comercio sacan los materiales y plata de España para siempre (...). La segunda es, porque extranjeros tienen deshauciada a España, pues la prosperidad que suele ser la vida de otros reinos, es la muerte de España (...). Porque en toda prosperidad de España tiene parte el extranjero y no sólo se la chupa y quita a España, sino que lleva todo ello a los enemigos y los arma contra España, de que le resulta gran peligro» 23 .

Lo cierto es que en el siglo XVII Castilla era, industrialmente hablando, inferior a otros países europeos -Francia, Inglaterra, Países Bajos-. Además el desnivel entre los precios de España y los del resto de Europa, sea cual fuere su origen, provocaba la entrada de productos extranjeros con las consiguientes nefastas consecuencias para nuestra economía.

Aun aceptando las repercusiones negativas motivadas por el exceso de fiestas, no hay que olvidar que la importación en Castilla estaba fuertemente primada, mientras que se castigaba la exportación ${ }^{24}$. Además las ventajas concedidas por el Estado español a los productos de sus dominios en Flandes o Italia, iba en perjuicio del proteccionismo necesario a los productos españoles.

En el último tercio del siglo XVII hubo intentos de solucionar estos problemas. Así, a fines de 1677, se encargó al duque de Villahermosa, Gobernador de los Países Bajos y a don Manuel de Lira, Embajador español en La Haya, el reclutamiento de artesanos ingleses y holandeses, especialistas en pañerías, para su instalación en la Península ${ }^{25}$.

\footnotetext{
Fernandez Navarrete, P., op. cit., Discurso XIII.

Moncada, S. de, Restauración política de España. Madrid, Instituto de Estudios Fiscales, 1974, pág. 101.

${ }^{24}$ Pal acio Atard, V., Derrota, agotamiento, decadencia, en la España del siglo xvil. Madrid, Rialp, 1966 , pág. 74.

25 Archivo General de Simancas (AGS), Estado, leg. 2739. Carta del Rey al duque de Villahermosa, de 26 de diciembre de 1677.
} 
Y el 29 de enero de 1679, Carlos II creó la Junta General de Comercio, como una proyección de la política económica mercantilista ${ }^{26}$. Tarea prioritaria de sus miembros fue la de informarse sobre el estado del comercio y las manufacturas en España, a la vez que se recababa información de los Embajadores en las Cortes extranjeras sobre sus respectivos comercios, a fin de imitar su industria y atajar las ganancias que con tanto exceso disfrutaban en nuestros dominios.

Una de las primeras medidas de la Junta fue la prohibición de traer géneros extranjeros, lo cual no resultaba novedoso ya que a lo largo del reinado de Felipe IV se había recurrido a la guerra económica con sus enemigos, prohibiendo el comercio con ellos, obteniéndose un escaso éxito ${ }^{27}$.

Iniciado ya el gobierno de don Juan José de Austria, se envió una orden para los corregidores, alcaldes..., con el objeto de que impidieran el comercio a los franceses en las ciudades con puerto de mar ${ }^{28}$, mientras desde Cádiz se elevaban protestas constantes, ante los fraudes cometidos en su puerto por los holandeses, los cuales introducian toda clase de géneros prohibidos, al tiempo que llevaban a cabo la saca de oro y plata.

Resulta indudable, pues, que el comercio seguía en manos de los extranjeros, quienes se aprovechaban de la escasa capacidad de negocio de los hispanos.

Por otra parte, con la prohibición del uso de productos extranjeros se creaba otro problema, consistente en la falta inicial de capacidad de las manufacturas peninsulares para abastecer todas las necesidades y ello se agravaba aún más, en el caso de las colonias americanas. Quizá por ello, en la siguiente centuria, Uztáriz se mostraba menos drástico que los arbitristas del siglo XVII:

“...comprendo que sería imprudente confianza y sobrada ambición, querer que todas las ventas, compras, permutas, transportes y demás negociaciones se hicieran por nosotros solos; pero tampoco es justo, ni decoroso, dar

Larruga y Boneta, E., Historia de la Junta de Comercio. Madrid, 1789. t. I, fols. 2-3.

Dominguez Ortiz, A., "Guerra económica y comercio extranjero en el reinado de Felipe IV". Hispania, t. XXIII, págs. 71-110.

it "Todos los franceses que se hallen en los puertos de estos nuestros Reinos, que no estuvieran ocupados en ministerios serviles y mecánicos, salgan luego de ellos y se retiren veinte leguas la tierra adentro y que en la misma forma salgan de esta nuestra Corte y doce leguas en contorno, los que se hallen en ella y porque conviene a nuestro servicio que en ninguna ciudad, villa o lugar (...) tengan trato, ni comercio alguno". Archivo Histórico Nacional (AHN), Consejos, lib. 1474, ํㅜ 10. Pragmática de 28 de septiembre de 1677. 
lugar, con nuestra indigencia y desacierto, a que sean los extranjeros solos los que las practiquen, disfrutando todas las utilidades que es razón se repartan entre todos (...). Me parece que no puede haber reparo alguno en que se manden observar puntualmente las leyes (...) a fin de facilitar que se trafique más por sus vasallos y en navíos propios" ${ }^{29}$.

Pero no sólo labradores, artesanos y comerciantes podían sufrir de alguna manera las pérdidas generadas por los días festivos, sino también hay que considerar la paralización de los tribunales de justicia en los meses de mayor movimiento agrícola, con el consiguiente retraso en la resolución de pleitos y causas:

"Se hallará que el mes de agosto, que es el más ocupado de todo el año con la cosecha de los labradores, tiene tantas fiestas como dias feriados; y si en este mes, el de septiembre y octubre, por ser en los que se recoge el pan y el vino, y se dispone la tierra para la nueva sementera, está prohibido por las leyes imperiales, renovadas en el código teodosiano, el traer a los labradores a los tribunales de justicia y ellos están excusados si no responden a las demandas, también parece justo se repare en que con tanta infinidad de fiestas, se impide al labrador su trabajo y en los tribunales de justicia y gracia se retarde el despacho con daño de los que esperan" ${ }^{30}$.

En relación con las protestas de algunos arbitristas ante la paralización de la justicia, en el ámbito de la agricultura en los meses de agosto, septiembre y octubre, conviene recordar que ya en el Decreto de Graciano se reproducian antiguas prohibiciones de celebrar causas judiciales, tanto por parte de eclesiásticos como de laicos, en domingo o en otras festividades de precepto. En 1234 el Liber Extra o Decretales de Gregorio IX volvían sobre el tema, para impedir la resolución de causas judiciales en días festivos ${ }^{31}$, con lo que quedaban verdaderamente limitadas las acciones judiciales a lo largo del año.

\section{LAS COFRADIAS}

Otro elemento inherente a las celebraciones religiosas y posible causante de repercusiones negativas en el ámbito económico eran las cofra-

\footnotetext{
29 UztáRIz, J. de, Theórica y práctica de Comercio y de Marina. Madrid, Aguilar, 1968, Capítulo CVII, págs. 396-397. Un siglo después de la publicación de la obra de Fernández Navarrete, Uztáriz insistia sobre el Discurso XIII de aquél, en torno a los perjuicios ocasionados a la economia por la excesiva proliferación de fiestas y días feriados. Véase Uztáriz, J. de , op. cit, págs. 408-409.

3c Fernandez Navarrete, P., op. cit., Discurso Xill.

31. Garcia Garcia, A., op. cit., pág. 37.
} 
días. Surgidas en la Edad Media como un instrumento en la lucha contra la herejia y un intento de uniformizar el culto en torno a unas devociones concretas, Trento las reorientó hacia el control de la vida religiosa y moral de la feligresía ${ }^{32}$.

Promovidas fundamentalmente por las órdenes mendicantes (franciscanos y dominicos), las cofradias se situaron en un plano intermedio entre Iglesia y sociedad. En España, en concreto, comenzaron a fundarse cofradias en el mundo urbano desde fines del siglo $\mathrm{xv}$, constituyendo el fermento religioso de los barrios y de los gremios ${ }^{33}$. A partir del siglo XVI se expansionaron penetrando en el mundo rural durante todo el siglo xvII y la primera mitad del siglo XVIII.

Las cofradias de los pueblos estaban dedicadas generalmente a algún santo. En su mayoria dependian de las aportaciones de sus componentes y de las limosnas obtenidas durante sus fiestas. Con ello procuraban pagar los gastos generados por sus ceremonias, el aceite de las lámparas, sus banquetes anuales, sus obras de caridad, los fuegos de artificio y todo aquello que consideraban oportuno a la hora de confraternizar.

Las cofradías representaban una doble incidencia en el ámbito económico. Por un lado, suponían pérdida de jornales laborales para sus miembros, entretenidos en festejos, reuniones,... Pero además, su mantenimiento podia resultar oneroso para determinados municipios y para los vecinos:

"También es conveniente reparar en que con tanto número de cofradías. hermandades y esclavitudes, se anden los oficiales la mitad del año atendiendo más a las emulaciones y competencias que a la devoción y a las diligencias necesarias para gozar de las indulgencias y que las cofradias de un arte o de un oficio, son ocasionadas a monopolios; y no obstante que en su concesión se prohibe esto, vemos que las hay en esta Corte con no pequeño daño de la República, pues lo que en ellas tratan, es de vender más caras sus labores y mercaderias" ${ }^{34}$.

\footnotetext{
Mantecon Movellan. T. A., Contrarreforma y religiosidad popular en Cantabria. Las cofradias religiosas. Cantabria, 1990, pág. 37. Véase también Actas. Primer Congreso Nacional de Cofradias de Semana Santa. Zamora, 1988; Carasa Soro, P.. "La asistencia social y las cofradias en Burgos desde la crisis del Antiguo Régimen", Investigaciones Históricas. 3. Valladolid. 1982; Gumera Ravina, C. uLas associacions religiosas de laics a la Barcelona de la segunda meitat del segle xvIII", Actes. Primer Congrés d'Historia Moderna de Catalunya. Barcelona. 1984.

Christian, W. A., Jr., op. cit. pág. 69

Ferinnandez Navahre ie., P., op. cit., Discurso XIII.
} 
Mantecón resume de forma clara y concisa los gastos generados por las cofradías, distinguiendo tres amplias zonas ${ }^{35}$ :

Franja septentrional, desde Galicia hasta Cataluña, con gastos inferiores a los 500 reales por cofradía y año.

Área Central, con gastos entre 500 y 700 reales.

Zona Meridional y vertiente levantina, con cifras que oscilan entre los 953 reales de Sevilla y los 1408 del Reino de Valencia.

Jerónimo de Uztáriz en su obra vuelve sobre el tema, al referirse al Discurso XIII de Fernández Navarrete sobre la muchedumbre de fiestas existentes en España y arremete de nuevo, en particular, contra el gran número de cofradias y hermandades ${ }^{36}$.

A mediados del siglo XVIII el mismo Padre Isla, a través de un pasaje de su obra, elaboraba una precisa crítica de las obligaciones socio-económicas que implicaba ser mayordomo de una cofradía. En este caso, el autor pone en boca de un labrador, mayordomo de sendas cofradías, la siguiente alocución:

\begin{abstract}
"¿Se servirá mucho a los santos en que un probe como yo gaste en cada una de estas mayordomias, sesenta reales en vino, veinte en tostada, diez en avellanas, todo para dar caridad a los cofrades, sin contar la cera, ni la comida a los señores sacerdotes, ni la limosna del padre predicador (...)? Ya la cera, la limosna del sermón y aunque digamos también la comida de los curas pase; porque todo esto parece cosa de Iglesia. Pero i el vino de los cofrades, que hay hombre que se mama dos cuartillos (...) , y añada su trinidad el baile por la tarde a la puerta del mayordomo..." ${ }^{37}$.
\end{abstract}

Aparte de los motivos económicos, el hecho de que las reuniones y actos de las cofradías degeneraran con frecuencia en actitudes violentas, explica sin duda la tendencia habida en la España Moderna en contra de esas asociaciones.

Ya en las Relaciones Topográficas de Felipe II aparecen indicios de la existencia de ciertos manejos contra ellas. En 1536 las constituciones de Toledo (repetidas en 1566 y 1601) anunciaban que en adelante no podrian establecerse nuevas cofradias sin licencia del ordinario:

\footnotetext{
35 Mantecón Movellán, T. A., op. cit., pág. 186. Estos gastos se sitúan en el último tercio del siglo XVIIl.

36 Uztáriz, J. de, op. cit., págs, 408-409.

${ }_{37}$ ISLA, J. F., Historia del famoso predicador Fray Gerundio de Campazas. Madrid, 1978, t. I, pág. 389.
} 
«porque han crescido y crescen en tanto número, que podrian traer daño» ${ }^{38}$.

En su primer Memorial para Trento, Juan de Ávila exponía ampliamente sus quejas contra las cofradías abogando por una de estas dos alternativas: o abolir las cofradías o ponerlas bajo la jurisdicción eclesiástica. En cualquiera de los dos casos, se mostraba partidario de consolidar los capitales de las distintas cofradías, con el fin de crear unos pocos hospitales grandes y eficientes, en vez de mantener muchos pequeños y caros $^{39}$.

Hacia 1580 se produjo la abolición de muchas cofradías y la concentración de sus bienes para dotar grandes hospitales. Esta decisión regia contó con el beneplácito del Papa. El problema resurgió con fuerza en el siglo XVIII. Próxima la caída del Antiguo Régimen, las cofradías religiosas representaban un estorbo para el curso que se iba imprimiendo a los ritmos de vida y de la economía. Según Larruga:

"...los días que habían de emplear en su trabajo, en cuidar que asistieran diariamente los oficiales y en procurar adelantar su caudal y cumplir con las obras encargadas, los emplean en visitarse unos a otros y en hacer intrigas con los amigos para el nombramiento de tesoreros, mayordomos, etc..." ${ }^{40}$.

Por ello el Consejo de Castilla se planteó la centralización y reforma de las cofradías. Entre 1773 y 1783 y emanadas de aquél, se sucedieron una serie de disposiciones legales por las que se disolvían las cofradías religiosas sin aprobación civil o eclesiástica, las de oficios debian transformarse en montepios y las que tuviesen sólo aprobación eclesiástica, quedaban suprimidas pero con posibilidad de integrarse en las Juntas de Caridad.

Fueron principalmente las cofradías del área costera andaluza y levantina, las que sirvieron como argumento a la iniciativa del Consejo.

\section{EL OCIO Y LA HOLGAZANERIA}

Se ha hablado mucho de la escasa laboriosidad de los campesinos en los siglos modernos. Los tratados e informes culpaban de ello al ex-

\footnotetext{
Citado por Christian, W. A., Jr., op. cit., pág. 204

Ibidem, pág. 205

Citado por Mante con Movfilan. T. A., op. cit., pág. 178.
} 
cesivo número de fiestas y al poco interés de los labradores por su trabajo. Por lo que respecta a esto último, en un informe del Intendente de Ciudad Real, Juan de Ipiña, dirigido al Consejo de Castilla, se decía que no trabajaban más que en los momentos cruciales de las cosechas y el resto del tiempo lo dedicaban al lujo y a la vagancia ${ }^{4}$. Resulta indudable que la agricultura estaba desprestigiada, de ahí el interés de los tratadistas por potenciarla:

«El estado de los labradores de España en estos tiempos está el más pobre y acabado y miserable y abatido de todos los demás estados (...). Y a tanto ha llegado, que suenan tan mal el nombre de labrador, que es 10 mismo que pechero, villano, grosero, malicioso y ahí abajo. A quien sólo adjudican las comidas groseras, los ajos y las cebollas, las migas y la cecina dura, la carne mortecina, el pan de cebada y centeno. Las abarcas, los sayos gironados (...). Las chozas y cabañas, las casas de tapias desmoronadas y caídas" ${ }^{42}$.

Porque una cosa era la ociosidad, que caracterizaba a un amplio sector del estamento nobiliario y cuyo origen estaba en su especialísimo código de honor y alejamiento de las actividades "mecánicas» ${ }^{43}$, y otra el ocio, que impulsado entre otras cosas por el excesivo número de fiestas, emergía en algunos agricultores conduciéndoles a la mendicidad y al vagabundeo.

Porque era especialmente fácil en la sociedad española del momento pasar de la ociosidad y holgazanería a la mendicidad; y de ésta, a la marginación social. A pesar de ello, también es cierto que el mendigo era más admisible que en otras sociedades. En España el pobre se sentía con derecho a pedir y la sociedad, de alguna manera, contaba con él. Así resultaba un elemento imprescindible en los días festivos, a la puerta de iglesias, ermitas, santuarios... ${ }^{44}$.

El pensamiento arbitrista fue una auténtica cruzada contra el ocio y en favor del trabajo productivo, tanto en la agricultura, como en la manufactura y el comercio. Martín González de Cellorigo señalaba que:

"Recogido por Donézar Difz de UlzurRún, J. Má., op. cit., pág. 454.

42 Este fragmento pertenece al Libro de las cinco excelencias del español que despueblan a España para su mayor potencia dilatación, de Benito de PENALOSA, publicado en 1629 y recogido por PERdices de Blas, L., La economía política de la decadencia de Castilla en el siglo xvil. Madrid, Sintesis, 1996. pág. 103.

43 Este ocio, tan criticado por los arbitristas del siglo $\times \mathrm{V}: 1$, ha sido estudiado recientemente por Perdices de Blas, L., op. cit., págs. 85-107.

44 Fernández Álvarez. M. La sociedad española en el Siglo de Oro. Madrid. Editora Nacional, 1984, pág. 180. 
"Es pretender ir contra la ordenación de Dios y dar en otros muchos errores, querer sacar fruto de la tierra sin trabajo, que no le da si no es con el sudor de nuestras manos" ${ }^{45}$.

Saavedra Fajardo, pensador profundo y político activo, que observó con detenimiento los fundamentos económicos del decaimiento español, hizo una excelsa alabanza del trabajo en su Empresa LXXI, titulada precisamente "Todo lo vence el trabajo" ${ }^{46}$.

También Fernández Navarrete insistió en la abundancia de pobres y holgazanes:

«Despuéblase asimismo Castilla por el poco cuidado y vigilancia que se tiene en castigar vagabundos y holgazanes, de que es infinito el número de estos reinos, siendo esta la causa de haber tantos pobres; (...) que el robusto trabajador siempre goza de abundancia, y el perezoso y holgazán siempre vive en la pobreza (...). Y es cosa digna de reparar el ver que todas las calles de Madrid están llenas de holgazanes y vagabundos, jugando todo el día a los naipes, aguardando la hora de ir a comer a los conventos y las de salir a robar las casas..." ${ }^{4}$.

Pero además Fernández Navarrete puso especialmente el acento en el ocio provocado por la excesiva proliferación de fiestas:

"Auméntase en España la holgazanería con la muchedumbre de fiestas de guardar que se ha introducido (...) a que se junta que los oficiales y labradores se habitúan a ser holgazanes (...) ${ }^{48}$. Suelen asimismo los reyes hacer grandes gastos en fiestas públicas, toros, cañas, torneos, (...), gastando en ellos, no liberal, sino pródigamente. No condeno estos regocijos públicos con que el pueblo se entretiene, desechando y olvidando la melancolía que le causa la pobreza (...); pero no han de ser ni tan frecuentes, ni continuas, que con ellas se habitúen los oficiales y trabajadores a la holgazanería, ni tan costosas que consuman las haciendas" ${ }^{49}$.

Sancho de Moncada se fijó, sobre todo, en el aprovechamiento que los extranjeros hicieron del carácter ocioso de los españoles:

"La ociosidad y holgazanería es vicio de los españoles bien conocido de extranjeros, y ellos entráronlos por aquí, aportillando el demonio este Reino,

Recogido por PERDICES DE BIAS, L., op. cit., págs. 87-88.

SaAvedra Fajardo, D. de, "Idea de un príncipe político-cristiano, representada en cien empresas", en Obras de Don Diego de Saavedra Fajardo y del licenciado Pedro Fernández Navarrete, BAE, tomo XXV. Empresa LXXI, págs. 195-197.

Ferinandez Navarrete, $P$., op. cit., Discurso IX.

Ibidem. Discurso XIII.

Ibidem, Discurso XXXII. 
por donde le halló flaco: traen todo lo necesario hecho de modo que no hay ya en qué trabajar; (...) y España está hoy tan haragana, ociosa, entumecida, y puedo decir que manca y baldada, que es menester ir a lo mismo a otros Reinos. $Y$ repare $V$. Magestad, si podemos escribir sin los extranjeros, pues no hay papel (...). De modo que ya no hay oficiales, porque no trabajan, porque no gastan lo que hacen, porque lo traen y venden los extranjeros... ${ }^{50}$.

Ya en el siglo XVIII, Jerónimo de Uztáriz insistía en los males que producía la muchedumbre de vagabundos existente ${ }^{51}$.

El Padre Feijóo, en cambio, atacaba más bien el ocio placentero de los días festivos:

"No hay duda en que debiendo ceder siempre los intereses temporales a los espirituales, debería darse por bien empleado el dispendio, que resulta de la suspensión de las obras serviles en los días festivos, como estos se aprovechasen en beneficio de las almas. Pero esto es lo que no sucede, antes todo lo contrario, en tanto grado que se puede asegurar, que más perjudica aquel ocio al alma que al cuerpo.(...). ¿En qué días, sino en los festivos, hay entre la gente común la concurrencia de uno y otro sexo al paseo. a la conversación, a la chocarrería, a la merienda y al baile? ¿Cuándo sino en las concurrencias, saltan las primeras chispas del amor torpe? ¿Cuándo si no en tales días se da al desorden de la embriaguez la gente de trabajo? En una palabra; las pasiones predominantes en cada temperamento, que en los demás días están como oprimidas de la fatiga corporal, se desahogan y lozanean en los festivos" 52 .

Ya en el siglo XVI, los Austrias Mayores lucharon contra el vagabundeo de los pobres, los cuales tendían al nomadismo buscando los lugares con más prósperas cosechas, o simplemente la rotación de las fiestas lugareñas. Carlos $V$ prohibió en reiteradas ocasiones ese vagabundeo: en Valladolid en 1523, en Toledo en 1525, en Madrid en 1528. Felipe II hizo lo propio en 1558.

Lo importante, no obstante, era hacer la distinción oportuna entre el pobre, forzado por la necesidad a mendigar y el holgazán ocioso que hacía de la mendicidad profesión, formando incluso parte del hampa.

Sobre todo en la segunda mitad del siglo XVIII, el vago era considerado, no como el pícaro tradicional sino como un delincuente. Las condiciones eran aptas para producir vagos y la caridad indiscriminada así como las dificultades económicas, contribuían a incrementar el número de

Moncada, S. de, op. cit., pág. 108.

UZTARIZ, J. de, op. cit., capítulos LIV, C y CVII.

FE:Jó, Fray B. J., op. cit, pág. 276. 
ociosos ${ }^{53}$. Durante la mayor parte del siglo XVIII, los vagos eran detenidos y conducidos al ejército, la marina y los astilleros ${ }^{54}$.

Las disposiciones reales, en una ciudad como Madrid, se sucedieron a lo largo de la centuria. Así en su afán por acabar con los mendigos de la Corte, Carlos III ordenó en 1766, que todos cuantos se hallaran en la Villa pidiendo limosna en nombre de ermitas, santuarios, comunidades, hospitales, santos u otro cualquier título, cesaran de pedir dicha limosna en el plazo de ocho días:

"Se retiren de esta Corte las cinco leguas de su rastro y de los Sitios Reales, pena de ser castigados como vagos, los seglares, y de extrañamiento del Reino a los que no lo fuesen con la sola reserva de aquéllos que lograsen licencia y permiso del Consejo para pedir limosna» 55.

Los edictos se sucedieron sin demasiado éxito. Ya en 1790, en el Diario de Madrid, del sábado 10 de julio, podía leerse:

“...por semejante providencia se vendría en pleno conocimiento de cada clase de individuos, con especialidad del jornalero, desocupado, vago, ocioso y mendigo voluntario; cuya clase de gente es la única de que debe cuidarse para que no permanezca en inacción, se apliquen al trabajo y no sean trabas y opositores a los progresos de la buena educación, política, policía, aseo...”.

También Mesonero Romanos hace continuas referencias a este problema en un tono marcadamente sarcástico:

"A esta industria colosal, aunque clasificada en diversas jerarquías y condiciones, se acogen y agrupan, según su respectivo instinto, medios y ventura, aquella inmensa cohorte de individuos que, sin más facultades que las tres del alma, sin más oficio que el de vivir, sin más porvenir que el del presente dia, amanecen en todos ellos sin saber a punto fijo si comerán o no, donde $y$ a qué hora» 56 .

\section{RESTRICCIÓN DE DIAAS FESTIVOS}

Así pues ante la proliferación de voces, que señalaban que el exceso de dias festivos suponia una pesada carga para los pobres, y una buena

\footnotetext{
$5:$ Véase Penez Estevez, Rosa $\mathrm{M}^{\mathrm{a}}$., El problema de los vagos en la España del siglo xvil. Madrid, 1976.

54 BNM, Mss. 18745, $n^{\circ}$ 13. Sobre recogida de vagabundos para su subsiguiente inserción en el ejército, en 1759 .

5 AHN, Consejos, lib. 1766, t. I1, fols. 382-448

56. Mesonero Romanos, R., Escenas Matritenses. Madrid, Aguilar, 1945, pág. 709
} 
ocasión para el ocio y el vicio, los obispos adoptaron medidas encaminadas a suavizar una situación juzgada de intolerable por muchos.

Juan de Ávila proponía que el precepto de no trabajar en tales días se limitara hasta la hora de la misa:

"Parece que la muchedumbre de las fiestas de holgar se debe restringir; y que sacados los domingos, no dure la obligación de las fiestas, sino hasta ser oida Misa maior " 57.

Sin ir más lejos, los obispos de Palencia (1545) y de Burgos (1575) concedieron permiso a las gentes para trabajar después de la misa en las fiestas votivas ${ }^{58}$, por la necesidad de trabajar puesto que muchas de ellas coincidian con la época de mayor trabajo (agosto).

A comienzos del siglo XVII, Fernández Navarrete abogaba por la retricción de los días festivos:

«... pero es lo que haciendo tan grande instancia en añadir fiestas no necesarias, se quebranten con tanta facilidad y sin necesidad precisa, las más solemnes, que la Iglesia con particular atención tiene instituido (...) y aunque hay tantas y tan importantes razones para celebrar las solemnidades de los Santos con actos exteriores que despiertan la devoción interior, se debe advertir que estas fiestas no sean gravosas al pueblo, ni costosas a los pobres, y asi conviene que la prudencia de los prelados las ajuste a que no cuesten lágrimas de los necesitados" ${ }^{59}$.

Saavedra Fajardo insistía igualmente en la necesidad de reducir las celebraciones festivas:

"Siendo pues tan conveniente el trabajo para la conservación de la república, procure el príncipe que se continúe y no se impida por el demasiado número de los días destinados para los divertimentos públicos, o por la ligereza piadosa en votallos las comunidades y ofrecellos al culto, asistiendo el pueblo en ellos más a divertimentos profanos que a los ejercicios religiosos. (...) ningún tributo mayor que una fiesta, en que cesan todas las artes, y como dijo San Crisóstomo, no se alegran los mártires de ser honrados con el dinero que lloran los pobres, y asi parece conveniente disponer de suerte los

ÁvILA, J. de, "Memorial 1 para Trento", 1551, en Miscelánea Comillas, 3, 1954, pág. 37; citado por Christian, W. A., Jr., op cit., págs. 315-316.

58 El voto y otras formas semejantes de petición a los santos, significaba un compromiso directo entre el cristiano y el mundo divino, sin ningún intermediario. Desde el punto de vista del derecho canónico, todo voto hecho a Dios, ya fuera guardar castidad, peregrinar a un santuario, ayunar.... debía ser cumplido so pena de incurrir en pecado mortal.

59. Fernandez Navarrete, P., op. cit., Discurso XIII. 
dias feriados y los sacros, que ni se falte a la piedad ni a las artes. Cuidado fue este del concilio maguntino en tiempo del papa León III, y lo será de los que ocupan la silla de San Pedro, como le tienen de todo, considerando si convendrá o no reducir las festividades a menor número, o mandar que se celebren algunas en los domingos más próximos a sus días" ${ }^{60}$.

En 1642 el Papa Urbano VIII promulgó un decreto por el que se permitía a las gentes trabajar en cualquier día, a excepción de un reducido número de días festivos. A mediados de la centuria la cuestión de las fiestas votivas resultaba especialmente gravosa dadas las condiciones críticas del campesinado castellano. Por ello la Iglesia se lanzó a la supresión de las fiestas locales aunque fracasó en su intento ${ }^{61}$.

Ya en el siglo XVIII, Uztáriz volvía a hacer referencia a las consideraciones realizadas por Saavedra, sobre la conveniencia de aminorar los días festivos y lo hacía de forma textual ${ }^{62}$.

El Padre Feijóo desde su Teatro Crítico Universal, atacaba sobre todo, la proliferación de fiestas locales, por lo que abogaba por la supresión de muchas de ellas:

"Argüiráseme que la Iglesia ha instituído todos los dias festivos que hay hoy, y es temeridad reprobar lo que la Iglesia instituye. Respondo lo primero, que dejando en pie las festividades que prescribió la silla apostólica, queda mucho que cercenar en las que introdujo la devoción de los pueblos (...). En atención a esto, parece pide hoy una piadosa equidad para España mucho mayor reforma de fiestas, que la que en otro tiempo hizo la santidad de Urbano VIII para toda la cristiandad. Este papa, en la bula Universa per orbem, expedida el año 1642, expresó ser movido para aquella reforma, no sólo por la representación que le hicieron muchos prelados del abuso que se hacía de los dias festivos, más también del perjuicio que padecian los pobres por la cesación de sus labores (...). Si hoy es mayor la necesidad de los pobres, es justo sea hoy mayor la reforma de las fiestas, por 10 menos, respecto de algunas provincias más pobres, como son las dos de Asturias y Galicia, cuyos labradores, trabajando con el mayor afán posible, sobre alimentarse todos misérrimamente, los más no ganan con qué cubrir sus carnes.

$\mathrm{Ni}$ es dudable que si los prelados que tienen presente esta angustia de sus súbditos, recurriesen con la representación de él a la benignidad de la silla apostólica, lograrian para ellos una gran rebaja de dias festivos (...). EI temperamento, que parece más proporcionado, para que, sin disonancia a la cristiana piedad, se concediese una considerable rebaja de dias festivos,

SaAvedra Fajardo, D. de, op. cit., Empresa LXXI. pág. 196

CHRISIIAN, W. A., Jr., op. cit.pág. 212.

UZTARIL, J. de, op. cit., pág. 409. 
sería dejar en estado de semifestivos, conservando la obligación de oir misa, y permitiendo en el resto del día, el trabajo $\Rightarrow 63$.

Es cierto que en distintos sínodos, la Iglesia puso de manifiesto el exceso de fiestas existentes, pero tenía motivos claros para hacerlo: a veces consideraba que las fiestas no se observaban de manera adecuada, quizás por su excesivo número. Otras veces la Iglesia se mostraba restrictiva o poco tolerante cuando veía en las prácticas de la religiosidad popular, aspectos supersticiosos, heréticos o que inducían a graves desórdenes.

Al parecer a la Iglesia no le preocupaban tanto las repercusiones económicas de las fiestas en el pueblo, aunque adoptó normas estrictas contra aquellas prácticas que implicaban evasiones fiscales, que trataban de eludir el pago de los diezmos, por ejemplo, u otros tributos debidos a la Iglesia.

Este desinterés de las elevadas jerarquías eclesiásticas, unido a la negativa popular de admitir la supresión de determinadas fiestas, sobre todo locales, explicaría la proliferación de voces clamando por la necesidad de aumentar los días laborables, a lo largo de los tiempos modernos.

53 FElJÖ, Fray B. J., op. cit., págs. 276-277. 